\title{
Effect of SAP0-34 molecular sieve morphology on methanol to olefins performance
}

\author{
WU Lei a,b, LIU Ziyu a,*, XIA Lin a, QIU Minghuang a, LIU Xu a , ZHU Haojia a, SUN Yuhan a,c,\# \\ a CAS Key Laboratory of Low-Carbon Conversion Science and Engineering, Shanghai Advanced Research Institute, Chinese Academy of Sciences, Shanghai \\ 201203, China \\ b University of Chinese Academy of Sciences, Beijing 100049, China \\ c State Key Laboratory of Coal Conversion, Institute of Coal Chemistry, Chinese Academy of Sciences, Taiyuan 030001, Shanxi, China
}

\section{A R T I C L E I N F O}

\section{Article history:}

Received 31 January 2013

Accepted 18 March 2013

Published 20 July 2013

\section{Keywords:}

SAPO-34 molecular sieve

Morphology

Methanol to olefins

Reaction temperature

Space velocity

\begin{abstract}
A B S T R A C T
SAPO-34 molecular sieve samples with sheet-like and cubic morphology were synthesized under microwave and hydrothermal conditions, respectively. The sheet-like SAPO-34 was $130 \mathrm{~nm}$ thick with a Brunauer-Emmett-Teller (BET) surface area of $593 \mathrm{~m}^{2} / \mathrm{g}$, while the cubic sample was 1.5-2.5 $\mu \mathrm{m}$ in size with a BET surface area of $708 \mathrm{~m}^{2} / \mathrm{g}$. Both samples exhibited a similar density for strong acid sites, while the cubic SAPO-34 possessed less weak acid sites. A methanol to olefins catalytic test carried out at $450{ }^{\circ} \mathrm{C}$ and $1.0 \mathrm{~h}^{-1}$ showed that the sheet-like SAPO-34 exhibited a long stability life of $380 \mathrm{~min}$ and gave a high ethylene selectivity of $51.77 \%$ and a high total selectivity for ethylene, propylene, and butylene of $90.20 \%$. However, the stability life for the cubic SAPO-34 was only $212 \mathrm{~min}$, and the ethylene selectivity and total selectivity for ethylene, propylene, and butylene decreased to $49.84 \%$ and $86.81 \%$, respectively. It is thought that the longer stability life and higher olefin selectivity for sheet-like SAPO-34 occur because of the shorter diffusion path that hinders the further conversion of produced olefins and coke formation.
\end{abstract}

(C) 2013, Dalian Institute of Chemical Physics, Chinese Academy of Sciences. Published by Elsevier B.V. All rights reserved.

\section{Introduction}

SAPO-34 molecular sieves exhibit excellent catalytic performance in the methanol to olefins (MTO) reaction because of their relatively small pore diameter, moderate acid strength, and highly hydrothermal stability [1-4]. Methanol conversions can reach $100 \%$ and the total selectivity for ethylene, propylene, and butylene can be over $80 \%$. However, SAPO-34 deactivates rapidly because of coke deposition, and this results in a short lifetime. Thus it is necessary to extend the lifetime of SAPO-34 in the MTO reaction by controlling coke deposition.

Many factors influence coke formation during the MTO reaction process, such as $\mathrm{Si} / \mathrm{Al}$ ratio [5], acidity [6], and crystal morphology $[7,8]$. In addition, catalytic conditions may also affect coke formation by controlling the relative distribution of products [9]. Obviously, improved MTO performance on SAPO-34 could be achieved by optimizing crystal morphology and catalytic conditions. In this work, SAPO-34 crystals with different morphologies were synthesized by controlling crystallization conditions. The samples were characterized by X-ray diffraction (XRD), scanning electron microscopy (SEM), energy-dispersive X-ray spectroscopy (EDX), Brunauer-EmmettTeller (BET) surface area determination, and ammonia temperature-programmed desorption ( $\mathrm{NH}_{3}$-TPD). The effects of crystal morphology and catalytic conditions on MTO performance were also investigated.

\footnotetext{
*Corresponding author. Tel: +86-21-20350958; Fax: +86-21-20350867; E-mail: liuziyu@sari.ac.cn \# Corresponding author. Tel: +86-21-20325009; Fax: +86-21-20325039; E-mail: sunyh@sari.ac.cn DOI: 10.1016/S1872-2067(12)60575-0 | http://www.sciencedirect.com/science/journal/18722067 | Chin. J. Catal., Vol. 34, No. 7, July 2013
} 


\section{Experimental}

\subsection{SAPO-34 preparation}

Pseudoboehmite ( 69 wt\% of $\mathrm{Al}_{2} \mathrm{O}_{3}$, Zibo Aluminum Co., Ltd., Zibo, China) was stirred with silica sol (31 wt\% of $\mathrm{SiO}_{2}$, Zhejiang Yuda Chemical Co., Ltd., Shangyu, China) and deionized water at room temperature. Then phosphoric acid (85 wt\%, Sinopharm Chemical Reagent Co., Ltd., Shanghai, China) and organic templates (tetraethyl ammonium hydroxide (TEAOH), 25 wt\%, Shanghai Nuotai Chemical Co., Ltd., Shanghai, China; or triethylamine (TEA), 99 wt\%, Shanghai Qiangshun Chemical Co., Ltd., Shanghai, China) were added successively to the above-mentioned solution under vigorous stirring to obtain milky uniform gels. Finally, the gels were transferred into Teflon-lined autoclaves and heated in a microwave oven (Milestone ETHOS A) or a rotating oven with predetermined heating programs under autogenous pressure. After crystallization, the autoclaves were cooled to room temperature, and the solid products were separated by centrifugation, washed thoroughly with deionized water, dried overnight at $120{ }^{\circ} \mathrm{C}$, and calcined at $550{ }^{\circ} \mathrm{C}$ for $6 \mathrm{~h}$ in a furnace. The resultant SAPO-34 samples were termed S-0, S-1, and S-2 (see Table 1 for corresponding crystallization conditions).

\subsection{Characterization}

XRD patterns were recorded using a powder X-ray diffractometer (Bruker AXS D8 ADVANCE) operated at $40 \mathrm{kV}$ and 40 $\mathrm{mA}$ using $\mathrm{Cu} K_{\alpha}$ radiation $(\lambda=0.154 \mathrm{~nm})$ in the range of $2 \theta=$ $5^{\circ}-40^{\circ}$. The crystal morphology of the S-0 sample was examined using a Hitachi S-4800 field emission-SEM (FE-SEM) microscope, and the crystal morphology and chemical compositions of S-1 and S-2 were examined by SEM using a Philips XL30 equipped with an EDX.

The textural parameters were measured by nitrogen adsorption isotherms using the Quantachrome AUTOSORB-IQ-MP system. The samples were first degassed for $6 \mathrm{~h}$ under vacuum at $300{ }^{\circ} \mathrm{C}$ and then tested at liquid nitrogen temperature. The micropore volume was determined using a $t$-plot method, and the pore size was calculated by the Horvath-Kawazoe (HK) method. The sample acidity was determined on a TP-5080 adsorption analyzer (Tianjin Xianquan Co., Ltd., China), where a $0.05 \mathrm{~g}$ sample was pretreated for $1 \mathrm{~h}$ at $400{ }^{\circ} \mathrm{C}$ in $\mathrm{Ar}(30$ $\mathrm{ml} / \mathrm{min}$ ) to remove the adsorbed water and then contacted with $\mathrm{NH}_{3}$ at $10 \mathrm{ml} / \mathrm{min}$ for $30 \mathrm{~min}$. Thereafter, Ar flow was introduced to remove the physically adsorbed $\mathrm{NH}_{3}$ molecules for $40 \mathrm{~min}$. The desorption process was carried out at $10^{\circ} \mathrm{C} / \mathrm{min}$ to

Table 1

Crystallization conditions for SAPO-34 samples.

\begin{tabular}{lcccc}
\hline Sample & Molar composition of gel & Heating method & $T /{ }^{\circ} \mathrm{C}$ & $t / h$ \\
\hline $\mathrm{S}-0$ & $1 \mathrm{Al}_{2} \mathrm{O}_{3}: 1.1 \mathrm{P}_{2} \mathrm{O}_{5}: 0.44 \mathrm{SiO}_{2}:$ & microwave & 165 & 0.75 \\
& $1.65 \mathrm{TEAOH}: 56.9 \mathrm{H}_{2} \mathrm{O}$ & & & \\
$\mathrm{S}-1$ & $1 \mathrm{Al}_{2} \mathrm{O}_{3}: 1.1 \mathrm{P}_{2} \mathrm{O}_{5}: 0.44 \mathrm{SiO}_{2}:$ & microwave & 220 & 2 \\
& $1.65 \mathrm{TEAOH}: 56.9 \mathrm{H}_{2} \mathrm{O}$ & & & \\
$\mathrm{S}-2$ & $1 \mathrm{Al}_{2} \mathrm{O}_{3}: 1.1 \mathrm{P}_{2} \mathrm{O}_{5}: 0.44 \mathrm{SiO}_{2}:$ & hydrothermal & 165 & 30 \\
& $2.25 \mathrm{TEA}: 31.4 \mathrm{H}_{2} \mathrm{O}$ & & & \\
\hline
\end{tabular}

$600{ }^{\circ} \mathrm{C}$. The amount of coke deposited on the deactivated SAPO-34 was characterized by thermogravimetry (TG) using a NETZSCH STA 449 F3 instrument.

\subsection{MTO reaction}

The MTO reaction over the SAPO-34 catalyst was performed in a fixed-bed reactor $(550 \mathrm{~mm} \times 12 \mathrm{~mm})$. SAPO-34 (3.0 g) was tableted to 20-40 mesh and then charged at the center of the reactor. Methanol aqueous solution (50 wt\%) was fed into the reactor under atmospheric pressure. The volume hourly space velocity (volume of methanol aqueous solution flowing through a unit volume of catalyst in a unit time) was $0.8-4.0 \mathrm{~h}^{-1}$, and the reaction temperature was $400-500{ }^{\circ} \mathrm{C}$. The gas products were analyzed using a SHIMADZU GC-2014C gas chromatograph equipped with a flame ionization detector and a HP-PLOT/Q column (30 $\mathrm{m} \times 0.53 \mathrm{~mm})$. The liquid products (mainly water and containing unconverted methanol when the conversion was lower than $100 \%$ ) were analyzed with a thermal conductivity detector and a PORAPAK T column $(3 \mathrm{~m} \times 3 \mathrm{~mm})$. Dimethyl ether (DME) was converted to the corresponding amount of methanol to obtain an accurate methanol conversion.

\section{Results and discussion}

\subsection{Characterization of SAPO-34}

\subsection{1. $X R D$}

The XRD patterns of the samples are given in Fig. 1. Only two weak characteristic peaks of SAPO-34 [10] at $2 \theta=9.6^{\circ}$ and $20.7^{\circ}$ appear in that of the S-0 sample. However, the characteristic peaks of SAPO-34 [10] appear at $2 \theta=9.6^{\circ}, 13^{\circ}, 15.9^{\circ}$, $20.7^{\circ}, 26^{\circ}$, and $31^{\circ}$ for the S-1 and S-2 sample with higher intensities, and no other peaks were detected. This implies that pure SAP0-34 is obtained. Figure 1 also shows that the peak intensities of the S-2 sample are higher than the other two samples, revealing the highest relative crystallinity of the S-2 sample.

\subsubsection{SEM}

Figure 2 depicts the FE-SEM and SEM images of the samples. The S- 0 sample (synthesized at $165^{\circ} \mathrm{C}$ for $0.75 \mathrm{~h}$ under micro-

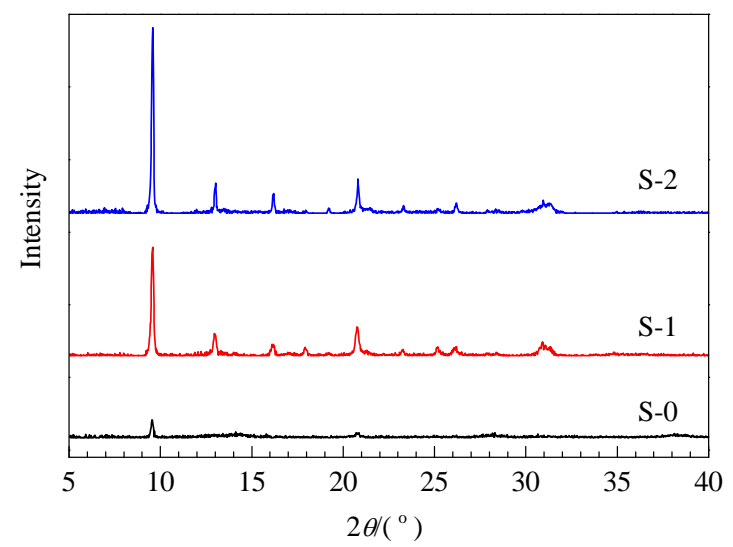

Fig. 1. XRD patterns of SAPO-34 samples. 


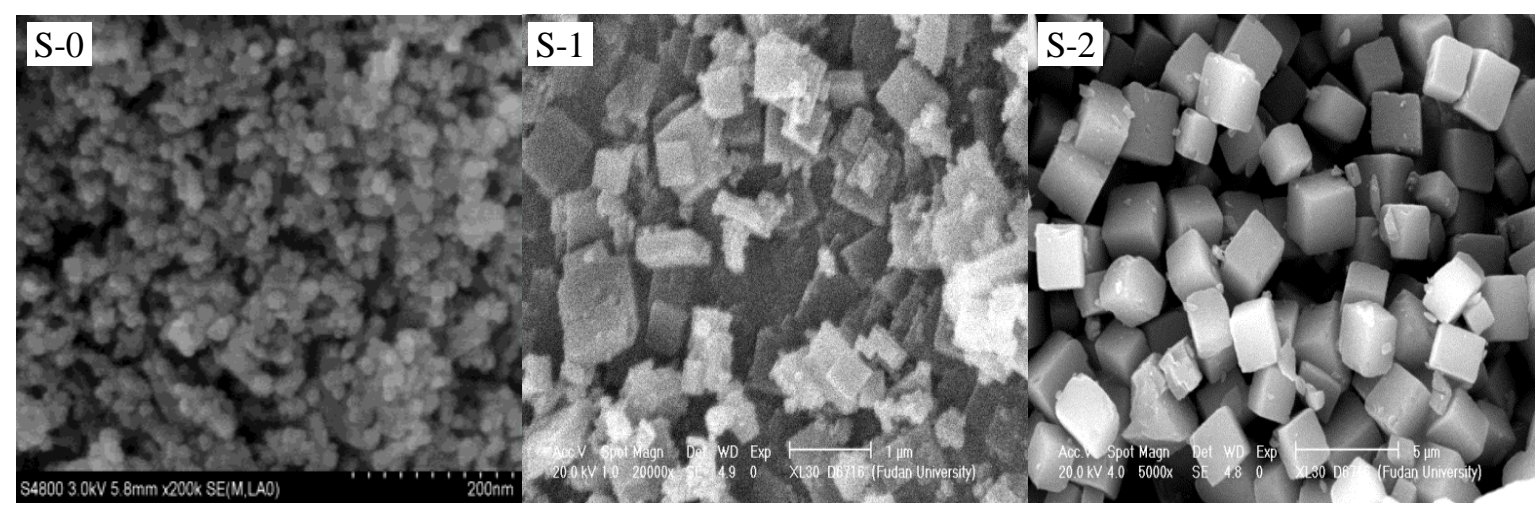

Fig. 2. FE-SEM (S-0) and SEM (S-1 and S-2) images of SAPO-34 samples.

wave conditions) yielded spherical SAP0-34 crystals of $20 \mathrm{~nm}$ diameter. By prolonging the crystallization time to $2 \mathrm{~h}$ at the same temperature, SAPO-34 with mixed aggregates of spherical and sheet-like crystals was formed. An increase in crystallization temperature to $220^{\circ} \mathrm{C}$ for $2 \mathrm{~h}$ under microwave conditions (S-1) yielded $1000 \mathrm{~nm} \times 1000 \mathrm{~nm} \times 130 \mathrm{~nm}$ sheet-like SAPO-34. However, the S-2 sample (synthesized under hydrothermal conditions at $165^{\circ} \mathrm{C}$ for $30 \mathrm{~h}$ ) had a larger cubic crystal structure of $1.5-2.5 \mu \mathrm{m}$. The SEM results show that there was a transformation process from spherical to sheet-like crystals under microwave conditions. Spherical crystals appear at low temperature and short crystallization time and transform to sheet-like crystals at higher temperature or with longer crystallization time.

\subsection{3. $E D X$}

The $n(\mathrm{Al}): n(\mathrm{Si}): n(\mathrm{P})$ for the $\mathrm{S}-1$ sample obtained by EDX is 0.48:0.10:0.42, while the value for S-2 is 0.51:0.07:0.42. The $P$ and $\mathrm{Al}$ contents of these two samples are almost identical while the Si content of S-1 is slightly higher than S-2.

\subsubsection{Nitrogen adsorption-desorption}

The nitrogen adsorption-desorption isotherms are presented in Fig. 3 with corresponding textural data listed in Table 2. Basically, both samples present the traditional type I isotherms, revealing the existence of micropores. The S-1 sample shows a hysteresis loop at high relative pressure, which may

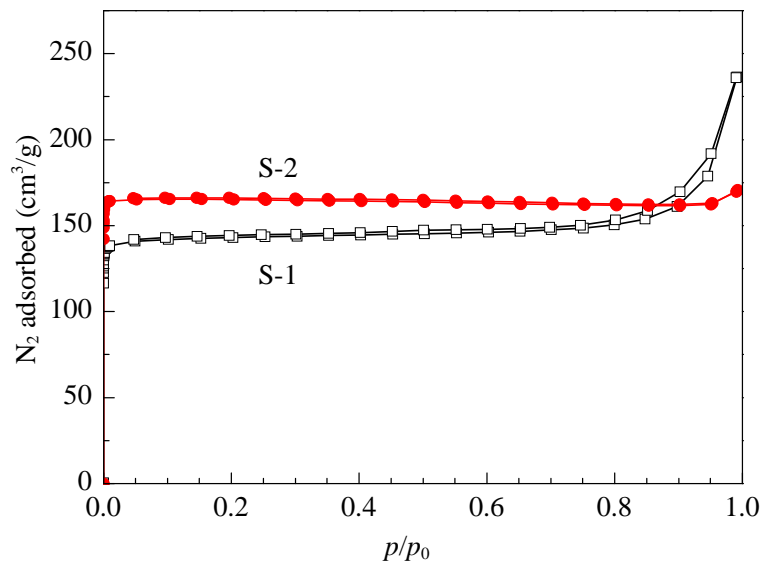

Fig. 3. Nitrogen adsorption-desorption isotherms of SAPO-34 samples.
Table 2

Textural data of SAPO-34 samples.

\begin{tabular}{lccc}
\hline Sample & $\begin{array}{c}\text { BET surface area } \\
\left(\mathrm{m}^{2} / \mathrm{g}\right)\end{array}$ & $\begin{array}{c}\text { Micropore volume } \\
\left(\mathrm{cm}^{3} / \mathrm{g}\right)\end{array}$ & $\begin{array}{c}\text { Pore size } \\
(\mathrm{nm})\end{array}$ \\
\hline $\mathrm{S}-1$ & 593 & 0.22 & 0.54 \\
$\mathrm{~S}-2$ & 708 & 0.26 & 0.54 \\
\hline
\end{tabular}

occur because of the condensation of nitrogen molecules on the external sample surface [11].

The BET surface area of S- 1 and S-2 is 593 and $708 \mathrm{~m}^{2} / \mathrm{g}$, respectively, and the micropore volume is 0.22 and $0.26 \mathrm{~cm}^{3} / \mathrm{g}$, respectively (Table 2). Therefore, a developed micropore system is formed in both samples. The difference in BET surface area between S-1 and S-2 may be caused by different crystallization conditions. The crystallization time for S-2 $(30 \mathrm{~h})$ is much longer than that for $\mathrm{S}-1 \mathrm{(} 2 \mathrm{~h})$, and the relative crystallinity of S-2 is also higher than that of S-1 (shown by XRD). The micropore system in S-2 may therefore be more developed, leading to a higher BET surface area. The pore size of both samples is $0.54 \mathrm{~nm}$, which is higher than the theoretical value $(0.38 \mathrm{~nm})$. This may occur because of connectivity between nearby channels.

\subsection{5. $\mathrm{NH}_{3}-\mathrm{TPD}$}

Figure 4 gives the $\mathrm{NH}_{3}$-TPD profiles of the SAPO-34 samples. Both samples possess peaks at approximately 160 and $370{ }^{\circ} \mathrm{C}$, which correspond to the weak and strong acid sites, respec-

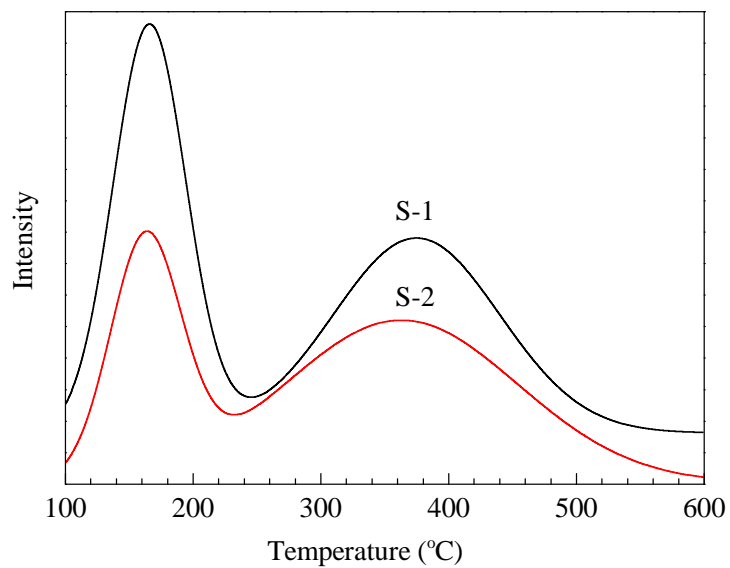

Fig. 4. $\mathrm{NH}_{3}$-TPD profiles of SAPO-34 samples. 
tively $[12,13]$. The desorption peak area of the weak acid sites for $\mathrm{S}-1$ is higher than that for S-2, implying that the amount of weak acid sites is higher in the former. This may be related to its higher Si content. However, the desorption peak area of the strong acid sites for both samples is almost the same, indicating the similar density for the strong acid sites in these two samples. It has been reported that the conversion of methanol to DME occurs mainly on the weak acid sites while the conversion of DME (and methanol) to light olefins occurs mainly on the strong acid sites $[14,15]$. The similar density for strong acid sites in these two samples reveals that acidity has little influence on the catalytic difference of the S- 1 and S-2 samples.

\section{2. $M T O$ reaction over $S A P O-34$}

\subsubsection{MTO performance}

Figure 5 gives the MTO performance on S-1 and S-2 under atmospheric pressure at $450{ }^{\circ} \mathrm{C}$ and $1.0 \mathrm{~h}^{-1}$. The methanol conversion on $\mathrm{S}-1$ is $100 \%$ for $380 \mathrm{~min}$ with an ethylene, propylene, and total selectivity for ethylene, propylene, and butylene of $51.77 \%, 36.86 \%$, and $90.20 \%$, respectively. In the case of S-2, the methanol conversion is $100 \%$ for $212 \mathrm{~min}$ with ethylene, propylene, and total selectivity for ethylene, propylene, and butylene being $49.84 \%, 34.22 \%$, and $86.81 \%$, respectively. Both the lifetime and selectivity for the light olefins on S-1 are superior to that on S-2. Taking into account their similar densi-

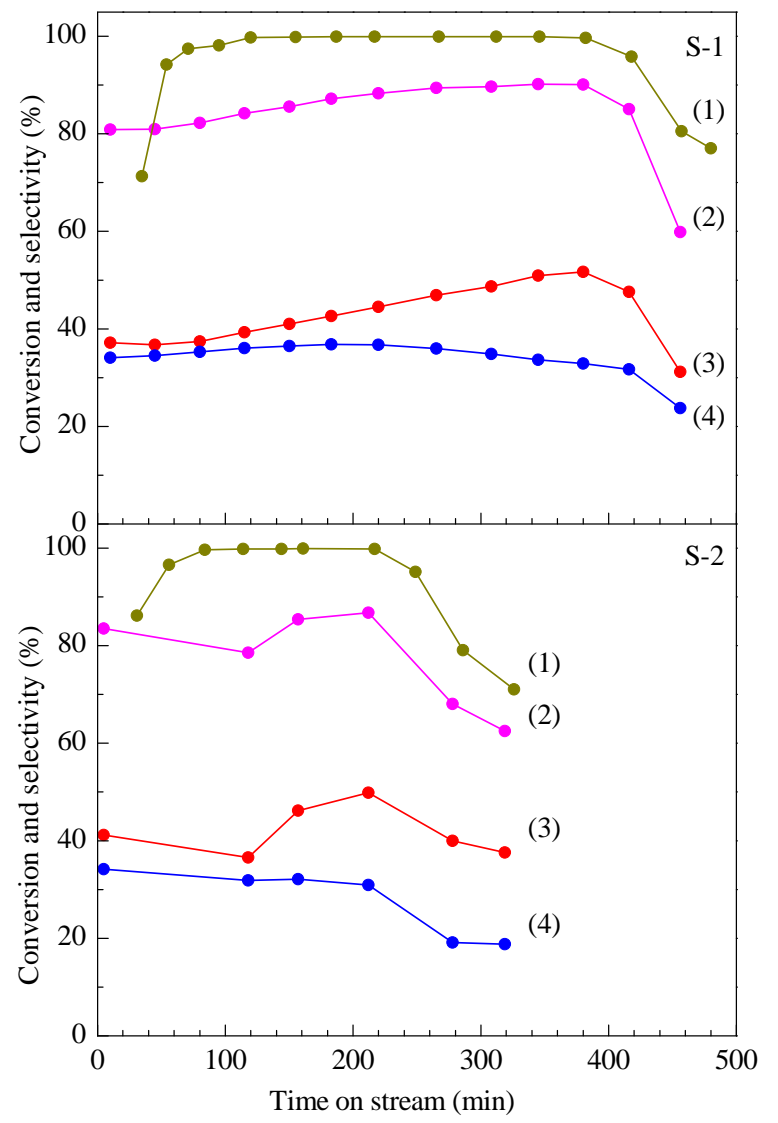

Fig. 5. MTO performance on SAPO-34 samples at $450{ }^{\circ} \mathrm{C}$ and $1.0 \mathrm{~h}^{-1}$. (1) Methanol conversion; (2) Total selectivity for ethylene, propylene, and butylene; (3) Selectivity for ethylene; (4) Selectivity for propylene. ty for the strong acid sites, this difference may arise from their different crystal morphologies [7]. The slice thickness of S-1 is $130 \mathrm{~nm}$, so the diffusion path is short. The ethylene and propylene can diffuse out of the SAPO-34 pores easily before being converted to heavier olefins, aromatics, and coke. Thus a higher light olefin selectivity as well as a longer lifetime are achieved. For S-2, however, the crystal size is larger and the diffusion path is longer than S-1. A second reaction for the produced light olefins and severe coke formation may occur, which would lead to a lower light olefin selectivity and shorter lifetime.

Figure 5 also shows that the total selectivity for the light olefins increases with time on stream. The ethylene selectivity also increases, but the propylene selectivity increases for a short time and then decreases. This may be ascribed to the changes in pore size caused by coke deposition [5]. The coke deposition reduced the SAPO-34 pore size, and the selectivity decreased for butylene with larger molecule size. The propylene molecules are smaller than those of butylene, thus the selectivity increases at the beginning and decreases with further reduction in pore size. The selectivity for the smallest ethylene molecules increases continuously, and the extent of increase is higher than the reduced extent of propylene and butylene. This results in an increasing total selectivity for the light olefins over a certain period of time.

\subsubsection{Effect of space velocity on MTO performance}

The methanol conversion on SAPO-34 sample S-1 at different space velocities and at $450{ }^{\circ} \mathrm{C}$ is shown in Fig. 6 . When the space velocity increases from 0.8 to $4.0 \mathrm{~h}^{-1}$, the lifetime decreases from 526 to $112 \mathrm{~min}$. The increasing space velocity leads to more molecules reacted per unit time, thus the coke formation rate increases, which decreases the lifetime of the SAPO-34.

\subsubsection{Effect of reaction temperature on MTO performance}

The methanol conversion on SAPO-34 sample S-1 at different reaction temperatures and at $1.0 \mathrm{~h}^{-1}$ is shown in Fig. 7. When the reaction temperature is maintained at $400{ }^{\circ} \mathrm{C}$, the methanol conversion is $100 \%$ for $644 \mathrm{~min}$. Then the conversion decreases slowly and is maintained at $93.26 \%$ to $791 \mathrm{~min}$. At

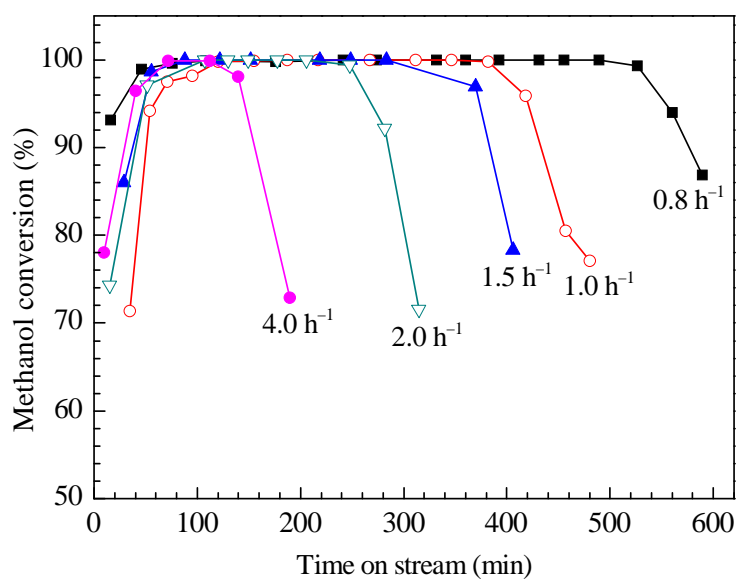

Fig. 6. Methanol conversion on SAPO-34 sample S-1 at different space velocities and at $450^{\circ} \mathrm{C}$. 


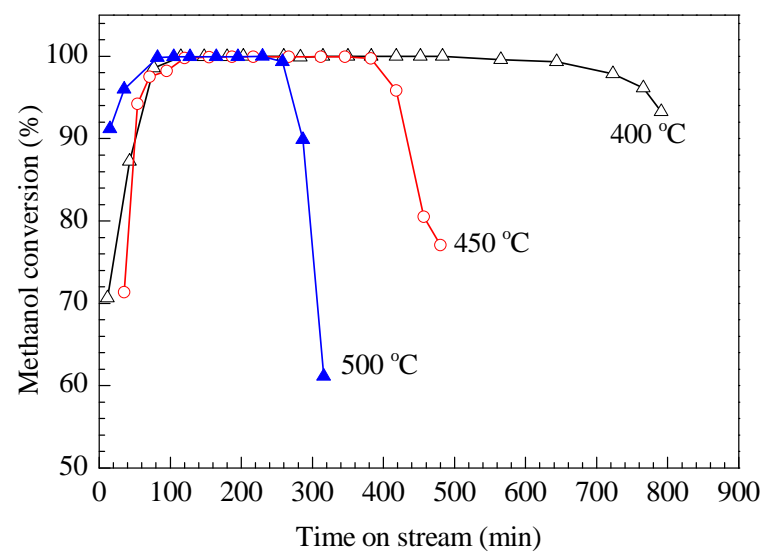

Fig. 7. Methanol conversion on SAPO-34 sample S-1 at different reaction temperatures and at $1.0 \mathrm{~h}^{-1}$.

$450{ }^{\circ} \mathrm{C}$, however, the methanol conversion is $100 \%$ for $380 \mathrm{~min}$ and then decreases rapidly. At $500{ }^{\circ} \mathrm{C}$, the methanol conversion is $100 \%$ for only $255 \mathrm{~min}$. These results indicate that the lifetime decreases with increasing reaction temperature, which may also result from the higher coke formation rate.

The selectivity for products on SAPO-34 sample S-1 at different reaction temperatures and at $1.0 \mathrm{~h}^{-1}$ is shown in Fig. 8. When the reaction temperature is $500{ }^{\circ} \mathrm{C}$, an ethylene selectivity of $56.96 \%$ can be achieved, which is far higher than the propylene selectivity. The butylene selectivity decreases from $7.81 \%$, and the total selectivity for ethylene, propylene, and butylene is $87.24 \%$. At $450{ }^{\circ} \mathrm{C}$, however, the highest ethylene selectivity is $51.77 \%$, which is still higher than the propylene selectivity but with a smaller difference compared with that $500{ }^{\circ} \mathrm{C}$. The butylene selectivity decreases from $9.63 \%$, and the total selectivity of $90.20 \%$ can be achieved. The highest ethylene selectivity at $400{ }^{\circ} \mathrm{C}$ is only $41.62 \%$, which is lower than the propylene selectivity. The butylene selectivity decreases from $14.04 \%$, but the total selectivity can be as high as $91.16 \%$. Figure 8 also shows that the selectivity for methane increases greatly at high temperature and can be higher than the butylene selectivity. That is, the selectivity for ethylene and methane increases, but the selectivity for propylene and butylene decreases with increasing reaction temperature; this leads to an increasing relative content of ethylene among the obtained light olefins. This phenomenon may be caused by the cracking of propylene and butylene into methane and ethylene at high temperature [16]. The above results also indicate that it is possible to control the relative olefin content by adjusting the MTO reaction temperature on the $\mathrm{S}-1$ sample.

\subsubsection{Coke analysis of deactivated SAPO-34}

The amount of coke on the deactivated SAPO-34 in Section 3.2.1 was analyzed by TG, and the coke formation rate was calculated based on these results as well as on the other characterization results (Table 3$)$. The coke formation rate for $\mathrm{S}-1$ is $0.043 \mathrm{mg} /\left(\mathrm{m}^{2} \cdot \mathrm{h}\right)$, which is half that for S-2 $\left(0.084 \mathrm{mg} /\left(\mathrm{m}^{2} \cdot \mathrm{h}\right)\right)$. The sheet-like crystals of S-1 can decrease the coke formation rate, thereby improving the MTO performance and prolonging the SAPO-34 lifetime.

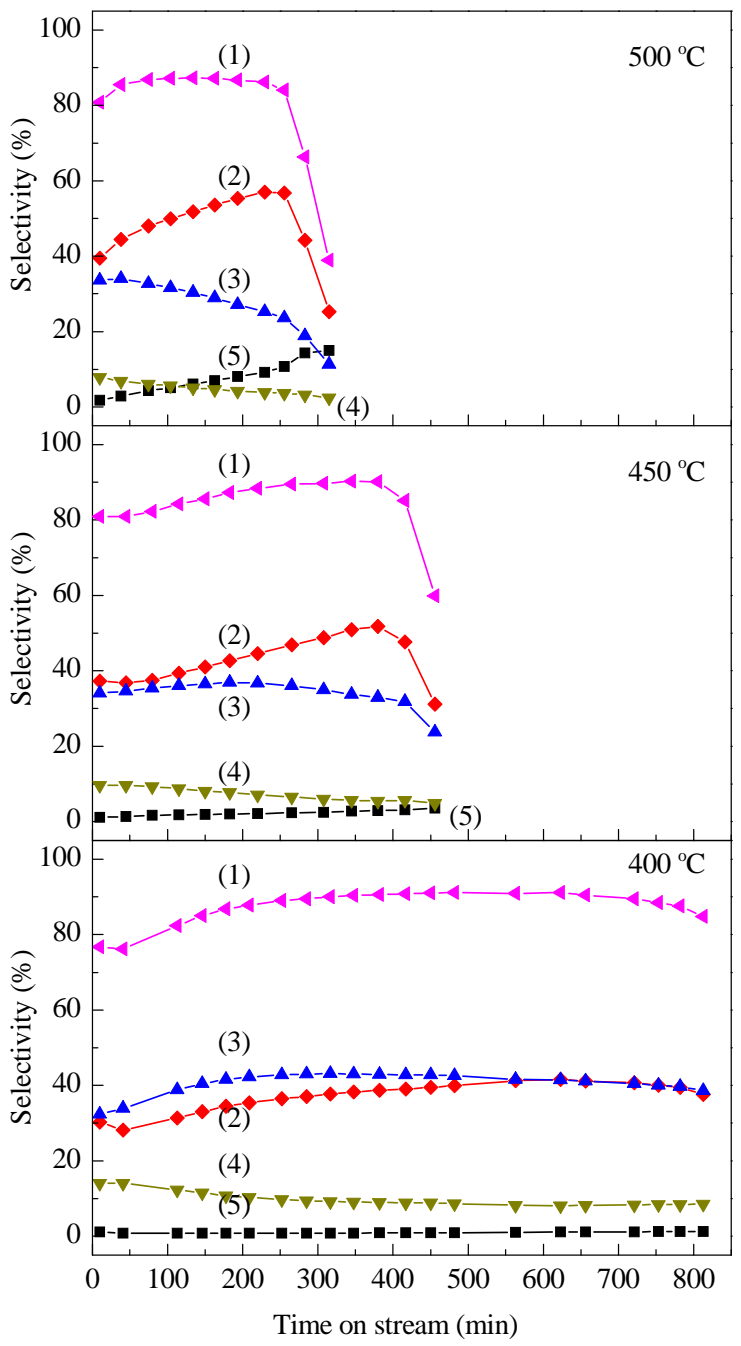

Fig. 8. Selectivity for products on SAPO-34 sample S-1 at different reaction temperatures and at $1.0 \mathrm{~h}^{-1}$. Selectivity for: (1) Ethylene, propylene, and butylene; (2) Ethylene; (3) Propylene; (4) Butylene; (5) Methane.

Table 3

Coke amount and coke formation rate of SAPO-34 samples.

\begin{tabular}{lccc}
\hline Sample & $\begin{array}{c}\text { Lifetime } \\
(\mathrm{min})\end{array}$ & $\begin{array}{c}\text { Coke amount per } \\
\text { surface area }\left(\mathrm{mg} / \mathrm{m}^{2}\right)\end{array}$ & $\begin{array}{c}\text { Coke formation } \\
\text { rate }^{\mathrm{a}}\left(\mathrm{mg} /\left(\mathrm{m}^{2} \cdot \mathrm{h}\right)\right)\end{array}$ \\
\hline $\mathrm{S}-1$ & 380 & 0.274 & 0.043 \\
$\mathrm{~S}-2$ & 212 & 0.296 & 0.084 \\
\hline
\end{tabular}

a Defined as the coke amount per surface area per lifetime.

\section{Conclusions}

The sheet-like SAPO-34 synthesized at $220^{\circ} \mathrm{C}$ for $2 \mathrm{~h}$ under microwave conditions had a thickness of $130 \mathrm{~nm}$ with a BET surface area of $593 \mathrm{~m}^{2} / \mathrm{g}$, while the cubic material synthesized at $165^{\circ} \mathrm{C}$ for $30 \mathrm{~h}$ under hydrothermal conditions was $1.5-2.5$ $\mu \mathrm{m}$ in size with a BET surface area of $708 \mathrm{~m}^{2} / \mathrm{g}$. Compared with the cubic one, the sheet-like SAPO-34 exhibited a longer lifetime of 380 min with higher ethylene selectivity of $51.77 \%$ and higher total selectivity for ethylene, propylene, and butylene of $90.20 \%$ in MTO process. The longer lifetime and higher olefin selectivity on sheet-like SAPO-34 were considered to come from the shorter diffusion path, which hindered further con- 


\title{
Graphical Abstract
}

Chin. J. Catal., 2013, 34: 1348-1356 doi: 10.1016/S1872-2067(12)60575-0

Effect of SAPO-34 molecular sieve morphology on methanol to olefins performance

WU Lei, LIU Ziyu*, XIA Lin, QIU Minghuang, LIU Xu, ZHU Haojia, SUN Yuhan*

Shanghai Advanced Research Institute, Chinese Academy of Sciences; University of Chinese Academy of Sciences; Institute of Coal Chemistry, Chinese Academy of Sciences
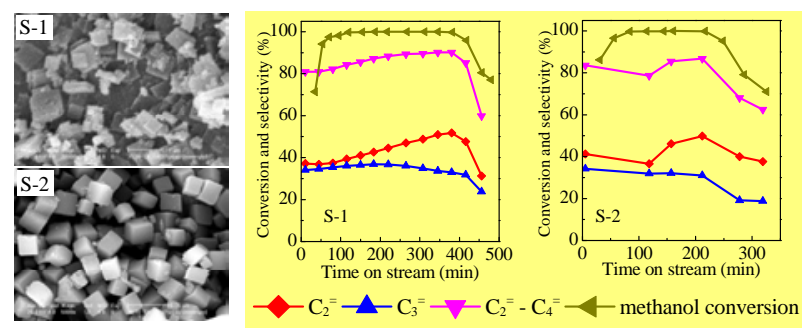

Methanol to olefins performance on SAPO-34 depends on the molecular sieve morphology. The sheet-like SAPO-34 (sample S-1) exhibits a longer lifetime and higher olefin selectivity than the cubic material (sample S-2) because of the shorter diffusion path of the former.

version of produced olefins and coke formation. For the sheet-like SAPO-34 sample, a high reaction temperature and high space velocity may accelerate the coke formation rate, leading to a fast deactivation of the catalyst. At the same time, the high reaction temperature improved the ethylene selectivity and decreased the propylene and butylene selectivity. The relative content of obtained olefins could be adjusted by controlling the MTO reaction temperature.

\section{References}

[1] Liang J, Li H Y, Zhao S G, Guo W G, Wang R H, Ying M L. Appl Catal, 1990, 64: 31

[2] Yuan C Y, Wei Y X, Xu L, Li J Zh, Xu Sh T, Zhou Y, Chen J R, Wang Q Y, Liu Zh M. Chin J Catal (袁翠峪, 魏迎旭, 许磊, 李金哲, 徐舒涛, 周游, 陈景润, 王全义, 刘中民. 催化学报), 2012, 33: 768

[3] Xu L, Du A P, Wei Y X, Meng Sh H, He Y L, Wang Y L, Yu Zh X, Zhang X Zh, Liu Zh M. Chin J Catal (许砧, 杜爱萍, 魏迎旭, 孟霜鹤, 何艳 丽, 王荣利, 于政锡, 张新志, 刘中民. 催化学报), 2008, 29: 727

[4] Liu G Y, Tian P, Xia Q H, Liu Zh M. J Nat Gas Chem, 2012, 21: 431

[5] Tang J Q, Ye L P, Ying W Y, Fang D Y. Petrochem Technol (唐君琴,
叶丽萍, 应卫勇, 房鼎业. 石油化工), 2010, 39: 22

[6] Ye L P, Cao F H, Ying W Y, Fang D Y, Sun Q W. J Porous Mater, 2011, 18: 225

[7] Chen D, Moljord K, Fuglerud T, Holmen A. Microporous Mesoporous Mater, 1999, 29: 191

[8] Álvaro-Muñoz T, Márquez-Álvarez C, Sastre E. Catal Today, 2012, 179: 27

[9] Li J Zh, Qi Y, Liu Zh M, Liu G Y, Chang F X. Chin J Catal (李金哲, 齐 越, 刘中民, 刘广宇, 常福祥. 催化学报), 2008, 29: 660

[10] Venna S R, Carreon M A.J Mater Chem, 2009, 19: 3138

[11] Marques A L S, Monteiro J L F, Pastore H O. Microporous Mesoporous Mater, 1999, 32: 131

[12] Campelo J M, Lafont F, Marinas J M, Ojeda M. Appl Catal A, 2000, 192: 85

[13] Lee Y J, Baek S C, Jun K W. Appl Catal A, 2007, 329: 130

[14] van Niekerk M J, Fletcher J C Q, O'Connor C T. Appl Catal A, 1996, 138: 135

[15] Travalloni L, Gomes A C L, Gaspar A B, da Silva M A P. Catal Today, 2008, 133-135: 406

[16] Li X H, Wang H T, Qi G Zh, Zhong S Q, Zhou X G, Xie Z K. Petrochem Technol (李晓红, 王洪涛, 齐国祯, 钟思青, 周兴贵, 谢在库. 石油 化工), 2009, 38: 1174

\section{SAPO-34晶粒形貌对甲醇转化制低碳烯烃反应的影响}

\author{
吴 䂞 ${ }^{\mathrm{a}, \mathrm{b}}$, 刘子玉 ${ }^{\mathrm{a}, *}$, 夏 林 ${ }^{\mathrm{a}}$, 丘明煌 ${ }^{\mathrm{a}}$, 刘 旭 ${ }^{\mathrm{a}}$, 朱浩佳 ${ }^{\mathrm{a}}$, 孙予罕 ${ }^{\mathrm{a}, \mathrm{c}, \text {, }}$ \\ a 中国科学院上海高等研究院低碳转化科学与工程中科院重点实验室, 上海 201203 \\ b 中国科学院大学, 北京 100049 \\ c中国科学院山西煤炭化学研究所煤炭转化国家重点实验室, 山西太原 030001
}

摘要: 分别采用微波和水热法合成了具有片状及立方结构的SAPO-34分子筷. 结果发现, 片状SAPO-34分子䇛晶粒厚度为130 nm, 比表面积为 $593 \mathrm{~m}^{2} / \mathrm{g}$; 立方结构SAPO-34分子笁粒径为 $1.5-2.5 \mu \mathrm{m}$, 比表面积为 $708 \mathrm{~m}^{2} / \mathrm{g}$. 二者具有数量相近的强酸中心, 后者的 弱酸位数量略少. 甲醇制烯烃反应结果表明, 在 $450{ }^{\circ} \mathrm{C}$ 和 $1.0 \mathrm{~h}^{-1}$ 的反应条件下, 片状SAPO-34分子篮的催化寿命可达 $380 \mathrm{~min}$, 乙烯 选择性最高为 $51.77 \%$, 乙烯、丙烯及丁烯的总选择性最高为 $90.20 \%$; 而立方结构SAPO-34的催化寿命仅为 212 min, 乙烯选择性最 高为 $49.84 \%$, 乙烯、丙烯及丁烯的总选择性最高只有 $86.81 \%$. 这可能源于片状晶粒的扩散路径较短, 抑制了低碳烯烃的进一步转 化及积碳的生成, 因此具有较高的低碳烯烃选择性及较长的寿命.

关键词: SAPO-34分子篮; 形貌; 甲醇制烯烃; 反应温度; 空速 
收稿日期: 2013-01-31. 接受日期: 2013-03-18. 出版日期: 2013-07-20.

*通讯联系人. 电话: (021)20350958; 传真: (021)20350867; 电子信箱: liuziyu@sari.ac.cn

通讯联系人. 电话: (021)20325009; 传真: (021)20325039; 电子信箱: sunyh@sari.ac.cn

本文的英文电子版由Elsevier出版社在ScienceDirect上出版(http://www.sciencedirect.com/science/journal/18722067).

\section{1. 前言}

SAPO-34分子篮具有相对较小的孔道直径、适宜的 酸强度以及高水热稳定性, 因而在甲醇转化制低碳烯烃 (MTO)反应中表现出优异的催化性能 ${ }^{[1-4]}$, 甲醇转化率可 达 $100 \%$, 乙烯、丙烯和丁烯的总选择性可超过 $80 \%$. 但 SAPO-34分子篮催化剂极易发生积碳失活, 催化寿命较 短, 因此延长SAPO-34分子篮在MTO反应中的催化寿命 具有重要意义.

积碳的生成与SAPO-34分子笁的硅铝比、酸中心的 强度及数量等因素相关 ${ }^{[5,6]}$, 而其晶粒形貌也会影响原料 及产物分子在孔道中的扩散过程, 进而影响积碳的生 成 ${ }^{[7,8]}$; 同时, MTO反应条件可通过产物的相对含量 ${ }^{[9]}$ 而 影响积碳的生成. 因此, 晶粒形貌及反应条件均会影响 SAPO-34分子笁上的MTO反应性能.

本文通过控制晶化条件合成了具有不同晶粒形貌 的SAPO-34分子篮, 采用X射线衍射(XRD)、扫描电镜 $(\mathrm{SEM}) 、 X$ 射线能量散射 $(E D X) 、 \mathrm{~N}_{2}$ 吸附-脱附及 $\mathrm{NH}_{3}$ 程 序升温脱附 $\left(\mathrm{NH}_{3}-\mathrm{TPD}\right)$ 等手段对SAPO-34分子篮进行了 表征, 考察了晶粒形貌及反应条件对SAPO-34分子篮上 MTO反应性能的影响.

\section{2. 实验部分}

\subsection{SAPO-34分子篮的合成}

将一定量的拟薄水铝石(淄博铝业公司, $\mathrm{Al}_{2} \mathrm{O}_{3}$ 质量 分数为 $69 \%$ )、硅溶胶(浙江宇达化工有限公司, $\mathrm{SiO}_{2}$ 质量 分数为 $31 \%$ )和去离子水混合, 在室温下搅拌均匀, 然后 依次加入磷酸(国药集团化学试剂有限公司, 质量分数 为 $85 \%$ )和有机胺模板剂(四乙基氢氧化铵 $(\mathrm{TEAOH})$, 上 海诺泰化工有限公司, 质量分数为 $25 \%$; 或三乙胺 (TEA), 上海强顺化工有限公司, 质量分数为 $99 \%$ ), 搅拌 均匀后制得凝胶. 然后将凝胶装入带有聚四氟乙烯内衬 的反应釜中, 密封后将反应釜放入微波反应器 (Milestone ETHOS A) 或转动烘箱中, 在预设加热程序和 自生压力下进行晶化. 晶化结束后, 待反应釜冷却至室 温, 将晶化产物洗涤至中性, 离心后将所得固体在 $120^{\circ} \mathrm{C}$ 干燥过夜, 于 $550{ }^{\circ} \mathrm{C}$ 焙烧 $6 \mathrm{~h}$, 即得SAPO-34分子篮样品, 分别命名为S-0, S-1和S-2 (三个样品的合成条件见表1).

\subsection{SAPO-34分子篮的表征}

XRD表征在Bruker公司的AXS D8 ADVANCE型X 射线粉末衍射仪上进行, $\mathrm{Cu} K_{\alpha}$ 靶 $(\lambda=0.154 \mathrm{~nm})$, 扫描范 围 $2 \theta=5^{\circ}-40^{\circ}$, 管电压 $40 \mathrm{kV}$, 管电流 $40 \mathrm{~mA}$. 样品 S-0 的 晶粒形貌采用 Hitachi 公司的 S-4800型场发射电镜 (FE-SEM)进行观察, 而样品S-1和S-2的晶粒形貌及化学 组成采用Philips公司的带有EDX的XL30型SEM进行观 察和测定. 样品的织构参数在 Quantachrome公司的 AUTOSORB-IQ-MP型物理吸附仪上测定, 样品先在 $300^{\circ} \mathrm{C}$ 及真空下脱气 $6 \mathrm{~h}$, 然后在液氮温度下测定样品的 $\mathrm{N}_{2}$ 吸附-脱附等温曲线, 分别通过 $t$-plot方法和HK方法算 得样品的微孔体积和孔径. 样品的酸性采用天津先权公 司的TP-5080型吸附仪测定. 测量时将 $0.05 \mathrm{~g}$ 焙烧后的样 品在 $400{ }^{\circ} \mathrm{C}$ 的 $\mathrm{Ar}(30 \mathrm{ml} / \mathrm{min})$ 下预处理 $1 \mathrm{~h}$, 以脱除样品上 吸附的水和其它杂质; 然后通入 $\mathrm{NH}_{3}(10 \mathrm{ml} / \mathrm{min})$, 持续 $30 \mathrm{~min}$; 再经 $\operatorname{Ar}$ 吹扫 $40 \mathrm{~min}$, 以除去样品表面物理吸附 的 $\mathrm{NH}_{3}$; 最后, 以 $10^{\circ} \mathrm{C} / \mathrm{min}$ 升至 $600{ }^{\circ} \mathrm{C}$ 进行程序升温脱 附. 失活SAPO-34分子篮的积碳量采用NETZSCH公司 的STA 449 F3型热重(TG)分析仪进行分析.

\section{3. 催化剂的评价}

MTO 反应在固定床反应器 $(550 \mathrm{~mm} \times 12 \mathrm{~mm})$ 中进 行, 内装3.0 g SAPO-34分子笁(20-40目). 以甲醇水溶液 (甲醇质量分数为 $50 \%$ ) 为原料, 反应条件为 $400-500{ }^{\circ} \mathrm{C}$, 常压, 体积空速(单位时间内流经单位体积催化剂的甲 醇水溶液体积) 0.8-4.0 $\mathrm{h}^{-1}$. 气相产物用 SHIMADZU GC-2014C型气相色谱仪分析, HP-PLOT/Q毛细管柱(30 $\mathrm{m} \times 0.53 \mathrm{~mm}$ ), FID检测器; 液相产物 (主要为水, 当转化 率低时也包含未转化的甲醇)用PORAPAK T毛细管柱(3 $\mathrm{m} \times 3 \mathrm{~mm}$ )和 $\mathrm{TCD}$ 检测. 产物中二甲醚 $(\mathrm{DME})$ 换算成相 应量的甲醇以获得真实的甲醇转化率.

\section{3. 结果与讨论}

\subsection{SAPO-34分子篮的表征结果}

\subsubsection{XRD结果}

图1为SAPO-34分子篮的XRD谱. 由图可见, S-0样 品在 $2 \theta=9.6^{\circ}$ 和 $20.7^{\circ}$ 处出现了 SAPO-34的特征峰 ${ }^{[10]}$, 且 强度较低; 而S-1和S-2样品在 $2 \theta=9.6^{\circ}, 13^{\circ}, 15.9^{\circ}, 20.7^{\circ}$, $26^{\circ}$ 和 $31^{\circ}$ 处出现SAPO-34分子篎的特征峰 ${ }^{[10]}$, 且强度高, 
没有出现其它衍射峰, 表明这两个样品均为纯相的 SAPO-34分子篮. 还可以看出, S-2样品的衍射峰强度最 高, 表明其相对结晶度最高.

\subsubsection{SEM结果}

图2为各SAPO-34分子篎样品的FE-SEM和SEM照 片. 由图可见, 在 $165^{\circ} \mathrm{C}$ 微波下晶化 $0.75 \mathrm{~h}$ 后得到的 S-0 样品是球形的, 其直径为 $20 \mathrm{~nm}$ 左右; 若将晶化时间延长 到 $2 \mathrm{~h}$, 则会得到球形与片状共存的样品, 说明部分球形 分子篮转变为片状结构; 在 $220{ }^{\circ} \mathrm{C}$ 微波下晶化 $2 \mathrm{~h}$ 后得到 的样品 S- 1 具有片状形貌, 其长和宽约为 $1 \mu \mathrm{m}$, 厚度为 $130 \mathrm{~nm}$ 左右; 而在 $165{ }^{\circ} \mathrm{C}$ 水热晶化 $30 \mathrm{~h}$ 后得到的样品 S-2 是具有立方结构的 SAPO-34 分子篮, 其粒径为 1.5-2.5 $\mu \mathrm{m}$, 明显大于 S-0和S-1样品的粒径. 由此可见, 在微波 条件下, SAPO-34分子篎的晶粒存在着由球形小颗粒向 片状晶粒转化的过程: 在低温短时间晶化条件下合成的 是球形小颗粒; 随着晶化时间的延长, 晶化温度的提高, 小颗粒逐渐消失, 最终生成片状SAPO-34晶粒.

\subsubsection{EDX结果}

EDX 测得 S-1 和 S-2 样品中 $n(\mathrm{Al}): n(\mathrm{Si}): n(\mathrm{P})$ 分别为 0.48:0.10:0.42和 0.51:0.07:0.42, 两者 $\mathrm{P}$ 和 $\mathrm{Al}$ 的含量基本相 当, 只是 $\mathrm{S}-1$ 样品的 $\mathrm{Si}$ 含量略高.

\subsection{4. $\mathrm{N}_{2}$ 吸附-脱附结果}

图3为SAPO-34分子篎的 $\mathrm{N}_{2}$ 吸附-脱附等温线, 表 2 为 相应的织构参数. 由图可见, S-1和S-2样品的等温线均 为典型的I型, 表明所合成的 SAPO-34分子篮为微孔结 构; S-1样品在高比压区内的弱迟滞环可能来源于 $\mathrm{N}_{2}$ 在 样品外表面上的凝聚 ${ }^{[11]}$. S-1和S-2样品的比表面积分别 达到 593 和 $708 \mathrm{~m}^{2} / \mathrm{g}$, 相应的微孔体积分别为 0.22 和 0.26 $\mathrm{cm}^{3} / \mathrm{g}$ (见表2), 表明这两个SAPO-34分子篮样品均形成 了发达的微孔体系; S-2的比表面积更高则可能是由其 晶化条件的差别所致. S-1样品在微波条件下晶化时间 较短, 而S-2样品在水热条件下晶化时间较长. 因此 S-2 样品的相对结晶度较高(见图1), 其内部微孔体系可能更 为发达, 因而其比表面积更大. 两者的孔径均为 $0.54 \mathrm{~nm}$, 比理论值 $(0.38 \mathrm{~nm})$ 偏高, 这可能是分子篮孔道之间有部 分连通所致.

\subsection{5. $\mathrm{NH}_{3}$-TPD结果}

图4为S-1和S-2样品的 $\mathrm{NH}_{3}$-TPD谱. 由图可见, 两样 品均出现两个脱附峰, 其中 $160{ }^{\circ} \mathrm{C}$ 左右的脱附峰对应于 弱酸中心, $370^{\circ} \mathrm{C}$ 左右的则对应于强酸中心 ${ }^{[12,13]}$. 相比 之下, S-1样品的弱酸中心脱附峰面积大于S-2样品, 表明 其弱酸中心数量略多, 这应与S-1样品中Si含量较多相
关; 而二者对应于强酸中心的脱附峰位置和峰面积差别 不明显, 表明其强酸中心强度和数量较接近. 一般说来, 弱酸中心主要使甲醇脱水生成DME, 而强酸中心则主要 将甲醇和DME的混合物转化为低碳烯烃 ${ }^{[14,15]}$. 二者强 酸中心的强度和数量较为接近, 表明在MTO反应中二者 酸中心的影响相差较小.

\subsection{SAPO-34分子篮的MTO反应结果}

\subsubsection{MTO反应结果}

在常压、 $450{ }^{\circ} \mathrm{C}$ 以及空速 $1.0 \mathrm{~h}^{-1}$ 的条件下各SAPO-34 样品上MTO反应结果见图5. 从图中可以看出, S-1样品 上甲醇转化率保持 $100 \%$ 的时间为 $380 \mathrm{~min}$, 乙烯选择性 最高为 $51.77 \%$, 丙烯选择性最高为 $36.86 \%$, 乙烯、丙烯及 丁烯的总选择性最高为 $90.20 \%$; 而 S-2样品上甲醇转化 率保持 $100 \%$ 的时间仅为 $212 \mathrm{~min}$, 乙烯选择性最高为 $49.84 \%$, 丙烯选择性最高为 $34.22 \%$, 乙烯、丙烯及丁烯的 总选择性最高为 $86.81 \%$. 可见, S-1样品的催化性能和稳 定性明显优于S-2样品. 考虑到这两个样品中对DME转 化为低碳烯烃起决定作用的强酸位数量较接近, 因此其 催化性能的差异应主要源自不同的晶粒形貌 ${ }^{[7]}$. S-1样 品晶粒厚度为 $130 \mathrm{~nm}$, 扩散路径较短, 因此生成的乙烯、 丙烯等低碳烯烃迅速扩散出孔道, 有效抑制了其进一步 生成高碳烯烃、芳烃以及形成积碳的反应, 因此低碳烯 烃的选择性较高, 催化寿命较长. 而S-2样品晶粒较大, 扩散路径较长, 不利于乙烯、丙烯等低碳烯烃从孔道中 及时扩散出来, 使得低碳烯烃较易进一步反应, 生成积 碳的速率较快, 导致低碳烯烃的选择性较低, 催化寿命 较短.

还可以发现, 在一定的反应阶段内S-1上烯烃的总 选择性随着反应时间的延长而增加, 同时乙烯选择性增 加, 而丙烯选择性则经历一段很短时间的增加后开始降 低. 这主要是由于积碳导致的孔道变化所致 ${ }^{[5]}$. 反应过 程中生成的积碳使SAPO-34的孔径减小, 丁烯的分子直 径较大, 因此其选择性逐渐下降; 丙烯的分子直径居中, 因此其选择性开始时逐渐增加, 而随着SAPO-34孔径的 进一步减小, 其生成被抑制, 选择性下降; 乙烯的选择性 则一直增加, 并且其增加量大于丙烯和丁烯的减少量, 使得烯烃的总选择性在一定的阶段内随着反应时间的 延长而提高.

\subsection{2. 空速的影响}

图6为不同空速下 S-1样品上甲醇转化率随反应时 间的变化. 由图可见, 当原料的体积空速从 $0.8 \mathrm{~h}^{-1}$ 升至 $4.0 \mathrm{~h}^{-1}$ 时, SAPO-34分子篮的催化寿命从526 min逐渐降 
至112 min. 这是因为随着空速的增加, 单位时间内发生 反应的分子数量逐渐增多, 使得积碳的生成量增加, 导 致SAPO-34分子篮的催化寿命逐渐降低.

\subsection{3. 反应温度的影响}

图7为不同反应温度下S-1样品上甲醇转化率随反 应时间的变化. 由图可见, 当反应温度为 $400{ }^{\circ} \mathrm{C}$ 时, 甲醇 转化率保持 $100 \%$ 的时间为644 min, 随后开始下降, 但降 幅较小, 至791 min时, 甲醇转化率仍可达 $93.26 \%$; 但当 反应温度为 $450{ }^{\circ} \mathrm{C}$ 时，甲醇转化率保持 $100 \%$ 的时间为 $380 \mathrm{~min}$, 之后迅速下降; 而当反应温度为 $500{ }^{\circ} \mathrm{C}$ 时, 甲 醇转化率保持 $100 \%$ 的时间仅为 $255 \mathrm{~min}$. 由此可见, 随 着反应温度的升高, 催化剂的寿命逐渐缩短. 这可能是 由高温下积碳的生成速率加快所致.

图8为不同反应温度下S-1样品上MTO反应产物的 选择性随反应时间的变化. 由图可见, $500{ }^{\circ} \mathrm{C}$ 下乙烯选 择性最高为 $56.96 \%$, 乙烯选择性明显高于丙烯, 丁烯选 择性从初始的 $7.81 \%$ 逐渐下降, 乙烯、丙烯及丁烯的总选 择性最高为 $87.24 \%$; 在 $450{ }^{\circ} \mathrm{C}$ 下, 乙烯选择性最高为 $51.77 \%$, 乙烯选择性仍高于丙烯, 但两者之间的差值较 $500{ }^{\circ} \mathrm{C}$ 时的小, 丁烯选择性从 $9.63 \%$ 逐渐下降, 乙烯、丙 烯及丁烯的总选择性最高为 $90.20 \%$; 而在 $400{ }^{\circ} \mathrm{C}$ 下, 乙 烯选择性最高仅为 $41.62 \%$, 始终低于丙烯, 丁烯选择性 从14.04\%逐渐下降, 但乙烯、丙烯及丁烯的总选择性高 达91.16\%. 另外，高温下甲烷的选择性随着反应时间的 延长而明显上升, 在反应后期甚至高于丁烯选择性. 可 见, 随着反应温度的升高, 乙烯和甲烷的选择性逐渐上 升, 而丙烯和丁烯的选择性逐渐降低, 使得乙烯在低碳 烯烃中的相对含量逐渐提高. 这可能是由于在高温条件
下丙烯和丁烯会发生裂解成甲烷和乙烯所致 ${ }^{[16]}$. 上述 结果表明, 可以通过控制片状结构的SAPO-34分子篮上 MTO反应温度来调节产物中各烯烃的相对含量, 以获得 不同的目标产物.

\subsection{4. 失活SAPO-34分子篮的积碳分析}

将3.2.1节中失活的SAPO-34分子篮通过TG分析其 积碳量, 并结合其它表征方法计算其积碳生成速率, 结 果见表3. 可以看出, S-1样品的积碳生成速率为 0.043 $\mathrm{mg} /\left(\mathrm{m}^{2} \cdot h\right)$, 远小于 $\mathrm{S}-2$ 样品的 $0.084 \mathrm{mg} /\left(\mathrm{m}^{2} \cdot h\right)$, 即 $\mathrm{S}-1$ 样品 的片状晶粒能有效抑制积碳的生成, 从而提高其催化性 能并延长催化剂的寿命.

\section{4. 结论}

$220{ }^{\circ} \mathrm{C}$ 微波条件下晶化 $2 \mathrm{~h}$ 后所得的SAPO-34分子 篮晶粒呈片状, 其厚度为 $130 \mathrm{~nm}$, 比表面积为 $593 \mathrm{~m}^{2} / \mathrm{g}$; 而 $165{ }^{\circ} \mathrm{C}$ 水热条件下晶化 $30 \mathrm{~h}$ 后所得的SAPO-34分子篮 晶粒呈立方结构, 粒径为 $1.5-2.5 \mu \mathrm{m}$, 比表面积为 708 $\mathrm{m}^{2} / \mathrm{g}$. 片状 SAPO-34分子篮的 MTO催化寿命可达 380 $\min$, 乙烯选择性最高为 $51.77 \%$, 乙烯、丙烯及丁烯的总 选择性最高为 $90.20 \%$, 均明显优于立方结构的SAPO-34 分子篮. 由于片状SAPO-34分子篮具有更短的扩散路 径, 能有效抑制低碳烯烃的进一步转化及积碳的生成, 因此具有较高的低碳烯烃选择性及较长的寿命. 对片状 SAPO-34分子篮来说, 较高的反应空速及较高的反应温 度将加快积碳的生成, 从而加速催化剂的失活. 同时, 高 温条件有利于提高MTO产物中乙烯的选择性, 降低丙烯 和丁烯的选择性, 因此可以通过控制反应温度来调节 MTO产物中各烯烃的相对含量. 